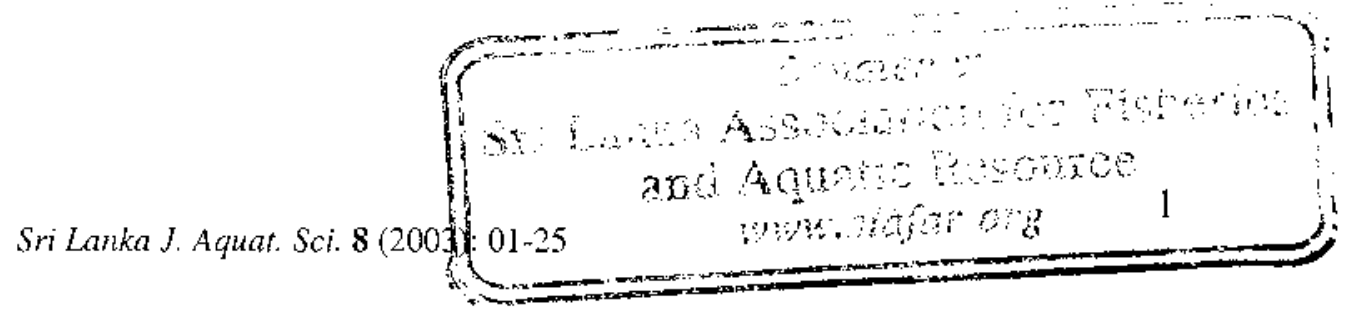

\title{
Perspectives and Economic Potential of Aquaculture of Tilapia: Experience in North-eastern Brazil Useful to Other Regions of the World
}

\author{
M.A. IGARASHI*, M.A. DE OLIVEIRA AND J.J.S. GURGEL \\ Department of Fisheries Engineering, Federal University of Ceará, \\ Ceará, Brazil
}

*Corresponding anthor (e-mail: igarashi@ufc.br)

\begin{abstract}
Brazil is an important producer and exporter of pork, beef and chicken, and fish is gaining way in to this field due to its gradual increase in production as a result of aquaculture. In 1996, tilapia was the mostly cultivated species representing approximately $32 \%$ of the total production of cultured fish. Hence, aquaculture, especially the culture of tilapia is showing considerable growth contributing significantly to socio-economic development and food production in Brazil as in many other regions of the world. Nevertheless, most of the consumers as well as the producers are continued to be misinformed of the positive aspects of aquaculture of tilapia, such as socio-economic development, generation of employment opportunities and foreign exchange earnings.

Around $70 \%$ of the country has a tropical climate, which favours the rapid growth of tilapia. Further, Brazil possesses a large number of inland water bodies, which represents approximately $12 \%$ of inland water's of the world. As such large amount of aquatic habitats of fresh water is available for aquaculture. Tilapia is a major source of animal protein for to about 44 million people living in this region.

The objective of this study is to evaluate the contribution of tilapia for the culture and capture fisheries in the north-eastern region of Brazil, especially in relation to socio-economic aspects. With adequate investment and management, aquaculture of tilapia can be successfully carried out in an environmentally friendly manner for the socio-economic stability in this region. The experience in the north-eastern region of Brazil will be very useful to develop tilapia culture in other regions of the world to combat protein malnutrition of the people and to generate foreign exchange through exportation of the product.
\end{abstract}




\section{M.A. Iragashiet al}

\section{Introductior:}

Aquaculture of tilapla was started in the west in Kenya in 1924 . Is 1937. rhese snecies were cultured also in Congo and by 1950 s they became the most promising spectes for aquaculture in the western world. in th: 1960s. much research was carrica out in the fiens such as adacuiturs. fishery biology, fishing technology and limnology which were imnoran for the develonment of eanture and culture fisnertes in the north-easter. region of Brazil im Lm:

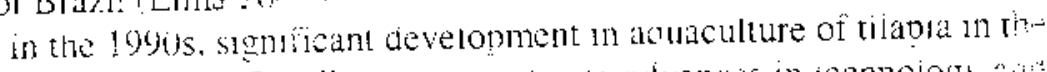
nortin-eastem regron of Birzil took olace due to advances in iecnnologt ane the introduction of new tilabia ineage. Aguaculture became intensive and super-mlensive, emplovitio lutge number or reservors and ner carres at. feeding with industranzes galanced ratons i Silva

Brazil is an important prociucer and exporter of pork neet an. chicken, and fish is gammg wav on to this fieio aue to its gradua increase : production as a resuli ol abuaculture. In 1996. of the total fish production o"

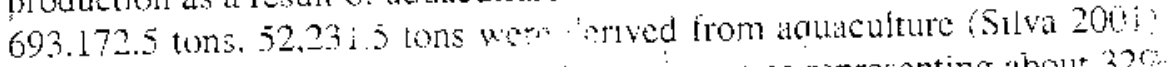
in 1990. tilapias were the ma. ate specles representing about $32 \%$ of the total production

Hence. ac. considerable

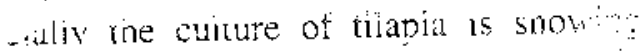
developme? inutner significantiv to socio-ecoro;: worki

Nevertheless. most of the consumers as weit as the produce.'; 2 re contunued to he misinformed of ine positive aspects of aquacuitur of tilapia, such as socio-conomic development, generation of empioytment; opportuntles and loreson exchange eamings Tus paper analyses the current situation of tiapla aquaculture in the semi-ario north-eastern resiog: of Brazij with spectai eierenes to socio-economic atrents.

\section{Aduacuiture production of tiasis}

\section{Giobai prodata}

in 1996, titapia producton of the world was 800.800 tons, shovise the highest percentage growth among the main groups of cultivated hisfi:. Five Asian countries contributed for 669.925 tons which was about $85 \%$ the total world production of tilapta, of which $48.8 \%$ was produced by China and $34 \%$ by the four oiner countries, namelv incionesia. Thailand. tic Philippines and Talwar (Table 1). Tilapia is the second most cultivates group of fish in the world. trailing behind only to carbs (FAO 1998 


\section{Tilapia in Brazil}

Tabs 1. Main producers of tilapia in the Wordd source: FAO 19997.

\begin{tabular}{lcc}
\hline Commry & \multicolumn{1}{c}{ Production } & \\
\hline & tons & $\%$ \\
\hline Chimit & 394.325 & 48.8 \\
Indonesial & 78,400 & 9.7 \\
Thuiland & 76.400 & 9.4 \\
Philippines & 76,000 & 9.4 \\
Taiwan & 44.800 & 5.5 \\
Brazil & 19,200 & 2.4 \\
\hline Total & 689.125 & 85.2 \\
\hline
\end{tabular}

Brazil has the potential to become one of the largest producers of cultured tilapia in the world mainly because it has a large number of water bodies appropriate for aquaculture and land is stailuble at fairly low prices. Furthermore, in the recent past the Brazilian population has grown in an enormous rate and therefore, the demand for tish has considerably increased.

\section{Aquaculture production in Brazil}

Lnti] 1995, the total aquaculture production in Brazil wats around 35,(000) tons/year. However, in 1998 it was around 115.000 tons (Ostrensky and Borghetti 2001) (Table 2).

Table 2. Aquaculture production of different groups and revenue generaled in Brazil (Source: Ostrensky and Borghetti 2001).

\begin{tabular}{|c|c|c|c|c|c|}
\hline \multirow[t]{2}{*}{ Group } & \multicolumn{2}{|c|}{ Quantity } & \multirow{2}{*}{$\begin{array}{l}\text { Price } \\
\text { per kg } \\
(\mathrm{R} \$)\end{array}$} & \multicolumn{2}{|l|}{ Revenue } \\
\hline & (tons) & $(\theta)$ & & Total $(\mathrm{R} \$)$ & (\%) \\
\hline Fish & 91,334 & 79.0 & 2.00 & $182,668,000$ & 62.1 \\
\hline Marine shrimps & 15.758 & 13.6 & 6.50 & $102,427,000$ & 34.8 \\
\hline Mussels & 07,900 & 6.8 & 0.75 & $5.925,000$ & 2.0 \\
\hline Oysters & 334,000 & 0.3 & 1.80 & 601,200 & 0.2 \\
\hline Frogs & $2+5,000$ & 0.2 & 7.00 & $1,715,000$ & 0.6 \\
\hline Freshwater shrimps & 90.000 & 0.1 & 8.50 & 765,000 & 0.3 \\
\hline Total & $115.66 \mathrm{l}$ & 100.0 & & 294.101 .200 & 1000 \\
\hline
\end{tabular}

(1) 2003. RS $1=$ LS S 0.35) 
The value of the aquaculture production in Brazil in 1998 was nearly RS $300,000,000.00$ with a mean price of $\mathrm{R} \$ 2.54 / \mathrm{kg}$ of the product. This average price is very close to the value estimated by FAO at global level, which is about $\mathrm{R} \$ 2.72 / \mathrm{kg}$ (Ostrensky and Borghetti 2001).

The Nile tilapia, Oreochromis niloticus is widely cultivated in Brazil as a pure or genetically improved variety (GIFT or Chitralada) together with two other introduced species, namely the Congo tilapia, Tilapia rendalli and the Zanzibar tilapia, Oreochromis hornorum. Two hybrids, i.e., the red tilapia (Oreochromis niloticus X Oreochromis aureus) and the hybrid tilapia of the Northeast (Oreochromis hornonum $\mathrm{X}$ Oreochromis niloticus), which were produced for the first time in the State of Ceará in 1972 are also used in aquaculture in Brazil (DNOCS 2000). Interest for tilapia cultivation has increased in the last nine years due to the introduction of the male production technology through sex reversal. With the development of this technology, individuals which can reach a size of $400-500 \mathrm{~g}$ within a culture cycle of one year in the south-eastern and southern regions of Brazil were produced. These fish fetch a high market price and are used in paid lishing activities. This has encouraged the expansion of cultivation not only extensively but also semi-intensively in water bodies fertilized with organic manure, intensively in "race-ways" and super intensively in floating lat cagcs.

In 1996, the til $;$ ruduction in Brazil was around 19,200 tons, which corresponded to $1+\%$ of the world production (Lima 2001a). From 1996 to 2001 , there was a nearly 3.5 fold increase in the production of tilapia, although the area under aquaculture increased only by about $32 \%$ (Table 3). About $75 \%$ of this production came from the southern region while the contribution from the north-eastern region was $<10 \%$ (Table 4)

Table 3. Tilapia production and the area used for aquaculture in Brazil from 1996 to 2001 (Source: Lima 2001a).

\begin{tabular}{lcccccc}
\hline & 1996 & 1997 & 1998 & 1999 & 2000 & 2001 \\
\hline $\begin{array}{l}\text { Production } \\
\text { (tons) }\end{array}$ & 19,200 & 26,250 & 35,405 & 42,918 & 58,265 & 69,912 \\
Area (ha) & 20,238 & 21,128 & 22,135 & 24,395 & 25,334 & 26,689 \\
\hline
\end{tabular}

The development of paid-fishing establishments is among the main factors that contributed to the growth of aquaculture of tilapia in the southern and south-eastern regions of Brazil. Paid-fishing establishments are made up of either a single fishery with little infra-structure or many fisheries with more infrastructure such as car parking, sleeping quarters, lighting for night fishing, restaurants, car parks, playgrounds for children and adult leisure grounds (game rooms, etc.). At paid-fishing establishments 
Tilapia in Brazil

tilapia may be purchased for $\mathrm{R} \$ 2.50 / \mathrm{kg}$. At some establishments of this nature in Ceará, where the extent is about $8 \mathrm{ha}$, about $1,000 \mathrm{~kg}$ of fish with prices ranging up to $\mathrm{R} \$ 4,00 / \mathrm{kg}$ were produced per week (Silva 2001).

Table 4. Tilapia production in different regions of Brazil in 1998 (Source: Lima 2001a) (to the nearest 1000).

\begin{tabular}{lrr}
\hline Region & $\begin{array}{r}\text { Production } \\
\text { (tons) }\end{array}$ & $\%$ \\
\hline Northerr/North-eastern & 3,000 & 7 \\
Mid west & 1,000 & 3 \\
South-castearn & 5,000 & 15 \\
Southern & 26,000 & 75 \\
\hline Total & 35,000 & 100 \\
\hline
\end{tabular}

On the other hand, in the north-eastern region, there is an enormous potential to increase the production in large reservoirs by fattening tilapia in cages. Besides this, through the cultivation of tilapia in dug-out ponds in rural areas and frequent stocking of public and private reservoirs, Brazil could become one of the largest producers and exporters of tilapia in the world.

\section{International market}

\section{Marketing of tilapia}

Japan, USA and the European Union are the major importers of fish in the world. These countries account for about $75 \%$ of the total imports which is valued at around US $\$ 2$ billion/year (Silva 2001).

In 1998, tilapia imports in USA were around 24,000 tons (Table 5). In that year, Brazil exported only 1.27 tons (Lima 2001a). In 1999, the USA imports reached a level of 37,570 tons of whole and cut tilapias which was equivalent to 60,785 tons of live weight (Silva 2001). The prices were also rewarding, live tilapia fetching a price of US\$ $13.19 \mathrm{~kg}$ and cold fillet fetching a price of US\$ $14.40 \mathrm{~kg}$ in the retail market. In USA, among the cultured species, tilapia is the third most important species followed by salmon and shrimp. The leading country which exports frozen tilapia fillets is Indonesia, while Costa Rica and Ecuador are the main countries which export cold fillets (Silva 2001).

The tilapia market in the European countries is based almost exclusively on imported products, as their total production is less than 360 tons per annum (Lima 2001a). 
Table 5. Tilapia imports by USA in 1998 (Source: Lima 2001a).

\begin{tabular}{lccc}
\hline & Tons & $\%$ & Price per Kg (US\$) \\
\hline Frozen whole & 14,400 & 60 & 1.57 \\
Fresh whole & 4,800 & 20 & 2.35 \\
Fresh fillet/cold fillets & 2,400 & 10 & 5.90 \\
Frozen fillets & 2.400 & 10 & 4.52 \\
\hline Total & 24,000 & 100 & \\
\hline
\end{tabular}

For the cconomic viability of aquaculture of tilapia in Brazil, it is necessary to prepare a development plan and provide organizational infrastructure to implement it. Further, providing technical assistance and support services and coordination of activities are also necessary. For the time being, already available organizational structure for processing and exporting marine fish could be utilized for this too.

\section{Marketing of tilapia in Brazil}

In Brazil, importation of captured and cultured fish increases annually. Increasing demand for fish in Brazil suggests that there is a high potential to market the cultured fish. The vast potential for aquaculture of tilapia in Brazil will result in the development of a sustainable sector capable of supplying cultured fish to local as well as international markets.

Currently, the manner of marketing of cultured tilapia in the northeastern region of Brazil is very precarious. This adversely affects the quality of the product due to lack of adequate infrastructure including fish entrepots, collection and resale stations, freezers and ice plants. However, these factors favour the intermediaries who keep a large $\%$ of the profit (Silva 2001). The intermediaries monopolize up to $72 \%$ of the profits. The wholesaler sells a small portion of the product at his own shop and stocks them for subsequent buyers. Further, the intermediaries negotiate the price with supermarkets, fish shops and restaurants (Silva 2001). Thus, the price of the product depends on those involved in the market chain. However, cultured tilapia necd not go through wholesale dealers and could be directly marketed to export companies, retail vendors, restaurants and consumers.

When tilapia comes to the market directly from the culture source, soon after being fished, the fish are fresh and preserved only by icing. For the local market, frozen tilapia fillets packed in plastic bags could be introduced. It is possible for the producers of tilapia to get $25 \%$ of the total profit whereas in the poultry and pork sector, the \% profit earned by the producers is $10 \%$ at the most (MAA 2000) 
At the cold storage plant, conditions of the tilapia are verified before they are processed or sold to consumers or retail vendors. This is important to negotiate a just price, for quality control and maintain good sanitary conditions.

Normally, the markets in Brazil are not geared to accept large quantities of tilapia coming directly from the farms, as there are not enough cold storage plants. In addition, tilapia is not a very popular fish among most of the Brazilians. However, in the north-eastern region of Brazil, there is a promising market for tilapia due to high demand from institutional restaurants (i.e. those in service enterprises, barracks, hospitals, schools etc.), and snack bars (Silva 2001). Nevertheless, in order to improve product quality and commercial organization, it is necessary to analyse the nature and availability of internal market and elaborate proposals for its development. These studies should include surveys on market procedures, consumer demand and the competition with marine fish.

\section{Competition with other species}

There is still much to be done to compete with other imported fish, which currently dominate the Brazilian market (Lima 2001b).

Manual processing plants with a capacity of handling 40-50 tons of cultured tilapia per week have been constructed in the States of Paraná and Santa Catarina.

Numerous small producers slice tilapia to sell in local markets. Tilapia weighing $350-500 \mathrm{~g}$ are filleted manually. Each fillet weighs $56-$ $84 \mathrm{~g}$. Tilapia fillets are sold fresh or frozen. Tilapia is also sold as whole fish on ice to neighbouring markets.

Cultured tilapia are also sold in street fairs, city markets, fish shops, supermarkets and other places as whole fish at a price of about RS4.00/kg and as frozen fillets at a price of R $\$ 7.80 / \mathrm{kg}$. Further, live tilapias are also sold in some fish shops in large north-eastern cities, such as Fortaleza and Recife (Silva 2001).

The main obstacles for competing at the international markets are associated with incipient structure of research institutions, insufficient knowledge on the market chains both at the local and international levels, lack of information regarding production costs and competition from other tilapia producing countries. However, for the international market, it is necessary to develop a strategic proposal, which guarantee the maintenance of the quality of the product throughout the entire process, from cultivation to processing. For this, it is necessary to consolidate on a HACCP system, which warrants quality during all stages of the processing procedure. Besides this, it is important to develop a strategy to popularise Brazilian 
tilapia by participating in fairs, congresses, and by direct intervention with importers.

\section{Consumption of fish in Brazil}

In 1998,40000 tons of prepared fish products (i.e., fish-sticks, fishburgers, nuggets, etc.) were imported to Brazil for local consumption (Lima 2001b).

Per capita consumption of fish in Brazil, is around $6 \mathrm{~kg}$ per annum, which is very low compared to international levels. Nevertheless there is high potential to increase this (Ribeiro et al. 2000). The Brazilians consume a total of 461,800 tons of fish of which $90.1 \%$ are marine fisb (Table 6).

Table 6. Annual consumption of fish in Brazil (Source: Ribeiro et al. 2000).

\begin{tabular}{lrr}
\hline Type of fish & \multicolumn{2}{c}{ Consumption } \\
\cline { 2 - 3 } & Tons & $\%$ \\
\hline Marine & 416,200 & 90.13 \\
Fresh water & 45,600 & 9.87 \\
\hline Total & 461,800 & 100.00 \\
\hline
\end{tabular}

However, in the northern region of Brazil annual per capita consumption of fish is around $55 \mathrm{~kg}$ mainly due high availabitity of fish caught from the Amazon (Lovshin 2000). In the north-eastern region, per capita fish consumption is only around $6.8 \mathrm{~kg} /$ year (Silva 2001). However, the World Health Organization (WHO) recommends a minimum per capita consumption of $15 \mathrm{~kg}$ of fish per/year. Accordingly, the total annual requirement of fish in the north-eastern region of Brazil is about is 670,500 tons.

It is estimated that about $60 \%$ of tilapia produced in the reservoirs in the north-eastern region is consumed in the villages located near the reservoirs as there are not much food options for the riverbank populations and also because the prices are within reach for most consumers (Silva 2001). Nevertheless, the north-eastern region purchases a considerable quantity of fish from other regions, i.e., from the southern and south-eastern regions, and also from other countries.

In the metropolitan region of Fortaleza in the north-eastern region, there are nearly 100 institutional restaurants, which serve more than 60,000 meals per day, with fish being served an average of 2-3 times per month in portions of $180-220 \mathrm{~g}$ per meal (Silva 2001). As such, this market alone has a demand for about 500 tons of fish per year. 


\section{Tilapia in Brazil}

Disintegration of the purchasing ability of the middle class may influence the future internal demand for tilapia. In any event, this sector should be prepared to function with more operational efficiency aiming at reducing production costs as well as the market price of tilapia.

\section{Socio economics and environmental considerations}

Approximately 44 million people live in the north-eastern region of Brazil. There is a high regional diversity in Brazil with regards to health, culture, industrializ.tion, population density and other socio-economic factors.

A large segment of the population in the interior of the northeastern region have no income at all, or survive with an income of less than US\$ 2.00 per day (Silva 2001). In this region, $61.5 \%$ of children who are less than 6 years of age are in families whose per capita income is less than half of the minimum recommended wage (Carvalho 2001).

The State of Ceará is in a semi-arid region and is characterized by scarcity of rains. It is one of the major factors responsible for low productivity and less availability of food resulting in high rate of poverty and hunger.

Exodus of people is very frequent from the rural areas where there are little labour options. Further, the fishery resources also appear to be depleting. Lack of information on production costs and financial return has also resulted in the withdrawal of investment in this sector.

To make matters worse the greenhouse effect has also negatively influenced the ecosystems both in the terrestrial and aquatic environments. The productivity potential in various regions has declined year by year. The rivers have dried-up and the agricultural areas have become unfertile resulting in grave problems for socio-economic development. Due to lack of rain, nutrient inflow into reservoirs, lakes, rivers and coastal marine waters has declined resulting in low biological productivity leading to low fish production.

In Brazil, $80 \%$ of the sewers discharge their effluents without any treatment. The government and local administration prefer to invest in ostentatious constructions, which bring in more votes. It should be emphasized that effluents must be treated prior to discharged into the environment. It was within this context that the sustainable use of biodiversity was recommended at the Biodiversity Convention held in 1992 in Rio de Janeiro where 172 countries participated.

The decline in the production of aquatic organisms in Brazil sounds as a warning signal to the lack of interest by the authorities with regards to sustainable use and conservation of aquatic resources in reservoirs, rivers 
and oceans. It is only the researchers who forewarn the dangers that result from unsustainable use of such resqurces.

\section{Sustainable development}

It is necessary to generate new employment opportunities for the increasing human population to provide means for their survival. If not, some other means should be developed for their maintenance. Fishing, mainly in reservoirs in the north-eastem region of Brazil, is an important activity that supplies animal protein to the rural populations at a low-cost. Therefore, rural people could be nourished and sufficiently catered by nature while maintaining the traditional cultures. Hence, by utilizing the nature in a sustainable manner, food produced in a particular region could be used by the people in that area.

Nourishment is also associated with the needs of the people and their culture. In the north-eastern region of Brazil, main source of animal protein has been meat by tradition. Although animal husbandry activities are carried out, it is necessary to carry out fishing too as an important altemative method of generating animal protein. For this, the communities should be organized to manage the capture fisheries, carry out aquaculture and marketing along with the protection and conservation of the environment. This has become necessary because fish production in the reservoirs of Ceará State has declised in certain regions even to a level that it is not sufficient in fes in iocal rural communities.

The research his shown that the chaotic situation of the Ceará State

may be overcome by aquaculture development, which will generate employment opportunities and income to the rural community as well as animal protein while maintaining the cultural eating habits based on the cultivation of aquatic organisms and fishing. This indicates that there is a possibility of utilizing aquatic resources and employing unoccupied lands for profitable productive activities, with the involvement of the rural community through the development of community associations while developing an ecological conscience.

The rapid expansion of aquaculture can lessen socio-economic problems faced by poor rural communities. However, it is important to give greater consideration to elaborate on the necessary production methods to maintain economic independence and self-sustainability. Furthermore, it is necessary that all people of the Ceará State unite their strength and knowledge to produce sufficient raw material for aquaculture. Intense research and investigations should also be carried out so that in the near future there will be sufficient production of fish and other aquatic organisms in the State. It is also necessary to pay attention to environmental safety and conservation of natural resources. Within this context, if fishing in the reservoirs is carried out without over-exploiting the natural stocks, 
it will be possible to utilize these resources in a self-sustained manner. If not, these resources will gradually diminish creating considerable socioeconomic problems.

\section{Feasibility of aquaculture of tilapia in rural areas in Brazil}

The reasons for bctter establishment of tilapia in some reservoirs in Brazil than in others, have been identified as follows (Silva 2001).

1) Water quality in reservoirs in the north-eastern region of Brazil is idcal for rapid growth of tilapia.

2) The fish species in most reservoirs are predominantly carnivorous, resulting in an efficient control of tilapia populations.

3) Commercial fishing in most reservoirs help to reduce tilapia populations

4) Polyculture of tilapia hybrid with several species of fish including common carp feeding with low protein diets also results in high yields.

5) Moreover, in most regions of Brazil, there is a tropical climate that allows aquaculture of tilapia throughout the year.

Protein malnutrition prevails in many parts of the north-eastern region of Brazil and fish can be used as low-cost protein source to overcome this problem.

Brazil is an important producer and exporter of grains such as soy and corn that can be used as supplementary feed for cultured fish.

Tilapia possesses desirable characteristics for aquaculture (Tables 7 and 8). Mainly because of its satisfactory growth and good quality meat, aquaculture of tilapia has shown promising perspectives. Satisfactory results have been already obtained by various private enterprises showing excellent economic viability. Due to lack of divulging mechanisms and operational support, a greater dissemination of these results has not been possible.

Besides this, polyculture of tilapia hybrid with fish species such as tambaqui, common carp and, pirapitinga, with supplementary feeding with low-protein has resulted in high conversion efficiencies (Silva 2001). Until recently, Nile tilapia was the most favoured species among producers. However, cultivation of red tilapia is also increasing rapidly due to high market demand. Among some of the qualities that make tilapia a suitable candidate for intensive aquaculture are high food conversion efficiency, high profitability, resistance to diseases, adaptation to various environmental conditions and consumption of low-priced food (Table 8). 
Table 7. Some information on Tilapia in Brazil (Source: Alves 2001).

\begin{tabular}{ll}
\hline No. of eggs/spawning in (thousand) & $50-200$ \\
No. of spawning/year & $6-8$ \\
Spawning location & Depression at bottom \\
Age at first reproduction & $4-5$ months \\
$\begin{array}{l}\text { No. of days of incubation } \\
\text { Ideal temperature for growth }\left({ }^{\circ} \mathrm{C}\right)\end{array}$ & 7 days \\
$\begin{array}{l}\text { Maximum weight that could be attained }(\mathrm{kg}) \\
\text { Weight at } 6 \text { months of age }(\mathrm{g})\end{array}$ & 50 \\
$\begin{array}{l}\text { Minimum dissolved oxygen required } \\
\text { superior growth (mg/l) }\end{array}$ & $300-400$ \\
Natural feeding habit & $2.5-3$ \\
Typical natural food & Omnivorous \\
Meat quality & Plankton, detritus \\
\hline
\end{tabular}

Table 8. Some characteristics of tilapia that make it a suitable candidate for intensive aquaculture (Source: Alves 2001).

Good consumer acceptance

Good market price

Low food conversion ratio

High efficiency in con'sting food in the lower tropic levels and low priced feed into fish flesh

Rapid growth

Large production but not excessive

Easy reproduction

Resistance to low levels of dissolved oxygen

Disease resistance

Resistance for rough handling

Consumption of low priced food.

The larvae and post larval can be fed by natural feed grown in rearing tanks by adding fertilizer

Resistance to metabolites dissolved in water

Large size of adults

Resistance to overcrowding

Easy adaptability to various environmental conditions

Easy catching

Easy preparation for consumption

Ability to withstand overcrowding

No cannibalism

Low amount of bones in flesh 
However, Reproduction during the first year of life is a problem faced by aquaculturists as this will reduce the rate of somatic growth. This problem can be overcome by monosex culture or using GIFT tilapia.

\section{Cultivation advantages}

Preference for tilapia as an edible species has grown significantly in the recent past in the north-eastern region of Brazil as well as internationally (Table 9). Within this context, a sustainable aquaculture of tilapia with low environmental impact appears to highly be required. Information related to cultivation, which is vital for the success of any program of aquaculture is also available at present.

Table 9: Results of the tropical fish tasting tests at the international fishing fair held in Ancona (lialy) in 1999 (Source: Lima 2001b).

\begin{tabular}{lc}
\hline Species & Score $(\mathbf{0 - 1 0})$ \\
\hline Tilapia & 9.1 \\
Peixe-rei & 8.0 \\
Surubim & 7.0 \\
Dourado & 6.2 \\
Traíra & 3.3 \\
Pacu & 3.1 \\
\hline
\end{tabular}

The advantages that Brazil has for aquaculture of tilapia are listed in Table 10 .

\section{Fingerling production}

There are 30 aquaculture stations in the north-eastern region of Brazil of which two are privately owned and 28 are public (Silva 2001). These stations are capable of producing approximately 150.5 million fingerlings/year, with an average of more than 5 million fingerlings per station per annum. These stations are spread throughout the droughtstricken Ceará State.

During the 68 years from 1933 to 1998 , more than 286 million fingerlings belonging to 31 species have been produced in the aquaculture stations in the north-eastern region of Brazil and during the 13 years from 1987 to 1999 more than 95 million fingerlings, which is about $33 \%$ of the total number produced have been stocked in the reservoirs of Ceará state (Table 11). It is estimated that a total of 210.5 million fingerlings of Congo and Nile tilapias are needed, annually for the reservoirs in the north-eastern region of Brazil (Silva 2001) of which 28.1 million are required for the reservoirs in the Ceará State. However, aquaculture stations in this State can 
Table 10: The advantages that Brazil has for aquaculture of tilapia (Source: Lima 2001b).

- $70 \%$ of the country has a tropical climate which favours the rapid growth of tilapia.

- Brazil possesses large number of inland water bodies, which represents approximately $12 \%$ of inland waters of the world. As such a large amount of fresh water habitats is available for aquaculture.

- The country is self-sufficient in grain production. Therefore, tilapia culture will be of added advantage to provide animal protein to the nation and earn foreign exchange by exporting the excess production.

- High amount of incident solar radiation resulting in high primary productivity in aquatic ecosystems.

- Autonomy for industrialized tilapia culture with government support.

- Availability of a nationalized local technology. In some projects, higher productivity than some of the best ones in the world was obtained using local technology.

Table 11. The number of fingerlings produced by pisciculture stations in the north-eastern region of Brazil and stocked in the reservoirs of Ceará State from 1933 to 1999 (Source: DNOCS 2000).

\begin{tabular}{lcccc}
\hline Period & $\begin{array}{c}\text { Number } \\
\text { of species }\end{array}$ & $\begin{array}{c}\text { Total } \\
\text { production }\end{array}$ & $\begin{array}{c}\text { No. Stocked in the } \\
\text { reservoirs in } \\
\text { Ceará State }\end{array}$ & $\begin{array}{c}\% \\
\text { Stocked }\end{array}$ \\
\hline $1933-86$ & 31 & $42,813,183$ & - & - \\
1987 & 12 & $6,264,629$ & $2,566,816$ & 40.9 \\
1988 & 23 & $15,227,149$ & $4,492,672$ & 29.5 \\
1989 & 25 & $21,852,976$ & $6,489,784$ & 29.7 \\
1990 & 20 & $16,885,746$ & $6,373,035$ & 37.7 \\
1991 & 15 & $18,304,076$ & $6,079,613$ & 33.2 \\
1992 & 14 & $18,937,584$ & $8,110,140$ & 42.8 \\
1993 & 15 & $16,6304,615$ & $5,841,945$ & 35.1 \\
1994 & 14 & $16,620,375$ & $5,087,175$ & 30.6 \\
1995 & 13 & $21,369,603$ & $8,868,045$ & 41.4 \\
1996 & 10 & $20,098,301$ & $7,682,441$ & 38.2 \\
1997 & 13 & $25,388,860$ & $10,590,729$ & 41.7 \\
1998 & 15 & $24,386,193$ & $12,334,298$ & 50.5 \\
1999 & 14 & $21,283,479$ & $10,590,729$ & 49.7 \\
\hline Total & 31 & 286,066769 & $95,107,427$ & 33.2 \\
\hline
\end{tabular}


produce only 26.5 million fingerlings per annum. It is necessary to carryout a well organised stocking program of the reservoirs and create policies to re-direct the development of tilapia culture with strategic planning. It is also necessary to regulate the supply of equipment required and facilitate technology transfer for fishermen and aquaculturists through technical assistance programmes.

\section{Present status of capture and culture fisheries in the north-eastern region of Brazil}

Therc are approximately 60,000 public and private reservoirs in the north-eastern region of Brazil, which cover an area of around 800,000 ha. The estimated fish production potential of these reservoirs is around 650,000 tons/year (Gurgel 1998). This region holds the largest volume of dammed up water in semi-arid regions of the world. Almost all these rescrvoirs are colonized with tilapia, indicating its importance in inland fish production. Silva (2001) suggested introducing 13 species of fish including Congo and Nile tilapias in the reservoirs of this region. The recommended minimum length of the fingerlings is $60 \mathrm{~mm}$. The presence of predators, including piranhas, seems to affect the tilapia production. Yet, according to Silva (2001) the presence of predators has, at times, contributed towards the control of population size of tilapias, which will eventually result in the production of large sized fish due to enhanced growth rate. Predation due to commercial fishing also contributes in a similar manner. About $44 \%$ of the fingerlings produced by pisciculture stations is Nile tilapia (Silva 2001). This indicates the importance of tilapia in reservoir fishery production in this region.

From 1979 to 1998 the mean number of fishermen at the public reservoirs in the north-eastern region of Brazil was 3,123. Their mean annual catch was 3.6 tons per fishermen of which tilapia contributed for 1.3 tons (Table 12).

The mean fish production in the reservoirs in the semi-arid northeastern region of Brazil is around $118.2 \mathrm{~kg} / \mathrm{ha} / \mathrm{yr}$. The Jaramataia reservoir in the State of Alagoas recorded the highest fish productivity of $1,989 \mathrm{~kg} / \mathrm{ha} / \mathrm{yr}$. About $60 \%$ of the fish produced in the reservoirs is consumed locally (Gurgel 1998). The average production of the shallow reservoirs in the north-eastern region, which have a mean depth of less than $2 \mathrm{~m}$, hatcheries and ponds when stocked with tilapia hybrid is given in Table 13.

Aquaculture of tilapia generates employment opportunities and income to rural population, thus resulting in well-defined socio-economic benefits. It is estimated that about 50,000 people depend directly on fishing in reservoirs in the semi-arid north-eastem region of Brazil. With an 
average productivity of $1.300 \mathrm{~kg}$ of tilapia per fisherman/yr, which is marketed at $\mathrm{R} \$ 2.50 / \mathrm{kg}$, the annual average income of a fisherman is estimated to be $\mathrm{R} \$ 3,250.00$, which is around $\mathrm{R} \$ 270.00 /$ month. However, in the real sense, it is estimated that the fisherman's share is merely $28 \%$ of the final retail price of tilapia (Silva 2001).

Table 12. Fish production and catch per fishermen in the public reservoirs in the north-eastem region of Brazil from 1979 to 1998 (Source: DNOCS 2000).

\begin{tabular}{|c|c|c|c|c|c|c|}
\hline \multirow[t]{2}{*}{ Year } & \multirow{2}{*}{$\begin{array}{l}\text { No. of } \\
\text { reservoirs }\end{array}$} & \multirow{2}{*}{$\begin{array}{l}\text { No. of } \\
\text { Fishermen }\end{array}$} & \multicolumn{2}{|c|}{ Production (tons) } & \multicolumn{2}{|c|}{$\begin{array}{c}\text { Production } \\
\text { (tons/Fisherman/year) }\end{array}$} \\
\hline & & & TOTAL & Tilapia & Total & Tilapia \\
\hline 1979 & 102 & 4,727 & 13,550 & 6,101 & 2.9 & 1.3 \\
\hline 1980 & 100 & 4,578 & 16,159 & 6,488 & 3.5 & 1.4 \\
\hline 1981 & 101 & 4,403 & 17,645 & 6,479 & 4.0 & 1.5 \\
\hline 1982 & 102 & 4,150 & 16,496 & 5,441 & 4.0 & 1.3 \\
\hline 1983 & 99 & 3,600 & 14,001 & 5,326 & 3.9 & 1.5 \\
\hline 1984 & 99 & 4,272 & 14,904 & 5,259 & 3.5 & 1.2 \\
\hline 1985 & 102 & 4,062 & 15,989 & 5,262 & 3.9 & 1.3 \\
\hline 1986 & 102 & 4,863 & 17,063 & 5,425 & 3.5 & 1.1 \\
\hline 1987 & 100 & 3,942 & 14,914 & 5,462 & 3.8 & 1.4 \\
\hline 1988 & 100 & 3,672 & 12,500 & 4,474 & 3.4 & 1.2 \\
\hline 1989 & 100 & 3,346 & 9,661 & 4,715 & 2.9 & 1.4 \\
\hline 1990 & 96 & 3,139 & 12,211 & 3.840 & 3.9 & 1.2 \\
\hline 1991 & 89 & 2,505 & 10,586 & 3,501 & 4.2 & 1.4 \\
\hline 1992 & 91 & 2,100 & 8,554 & 2,920 & 4.1 & 1.4 \\
\hline 1993 & 100 & 2,104 & 7,027 & 2,892 & 3.3 & 1.4 \\
\hline 1994 & 96 & 2,189 & 4,860 & 2.397 & 2.2 & 1.1 \\
\hline 1995 & 80 & 902 & 3,675 & 1,834 & 4.1 & 2.0 \\
\hline 1996 & 74 & 1,349 & 3,274 & 1,287 & 2.4 & 1.0 \\
\hline 1997 & 85 & 1,188 & 4,196 & 1,171 & 3.5 & 1.5 \\
\hline 1998 & 94 & 1,362 & 5,450 & 1,772 & 4.0 & 1.3 \\
\hline Mean & 96 & 3,123 & 11,136 & 4,134 & 3.6 & 1.3 \\
\hline
\end{tabular}

In 1986, the public reservoirs in the State of Ceará produced over 10.000 tons of fish (DNOCS, 2000). However, from I991 to 1996, it has decreased, and from 1997 it has again increased (Gurgel 2001). This increase is believed to be mainly due to an increase in the production area (Table 14). However, according to Silva (2001), in some reservoirs this increase is due to the introduction of $O$. niloticus. In some reservoirs $100 \%$ increase in fish production has been observed after the introduction of this species (Silva 2001). 
Tilapia in Brazil

Table 13. Fish production in the reservoirs, hatcheries and ponds in the north-eastern region of Brazil with different culture regimes (Source: Alves 2001).

\begin{tabular}{lc}
\hline Culture Regime & Production(t/ha/year) \\
\hline $\begin{array}{l}\text { Small reservoirs without fertilizing or } \\
\text { artificial feeding }\end{array}$ & $0.10-0.15$ \\
$\begin{array}{l}\text { Smail reservoirs with fertilizing } \\
\text { Small reservoirs with fertilizing and }\end{array}$ & $1-4$ \\
artificial feeding & $20-80$ \\
$\begin{array}{l}\text { Small reservoirs with artificial feeding and } \\
\text { aeration }\end{array}$ & $200-800$ \\
Hatchery with running water and artificial \\
feeding \\
$\begin{array}{l}\text { Circular ponds with circulating water and } \\
\text { artificial feeding }\end{array}$
\end{tabular}

Table 14. Fish production of public reservoirs in the State of Ceara' from 1989 to 1999 (Source: DNOCS 2000).

\begin{tabular}{lcccc}
\hline Year & $\begin{array}{c}\text { Number of } \\
\text { reservoirs }\end{array}$ & $\begin{array}{c}\text { Approximate } \\
\text { Surface area (ha) }\end{array}$ & $\begin{array}{c}\text { Production } \\
\text { (tons/ year) }\end{array}$ & $\begin{array}{c}\text { Production } \\
\text { per unit area } \\
\text { (kg/ha/yr) }\end{array}$ \\
\hline 1989 & 48 & 69.000 & $6,648.5$ & 96,3 \\
1990 & 47 & 68.600 & $6,385.0$ & 93,0 \\
1991 & 47 & 68.600 & $6,673.1$ & 97,2 \\
1992 & 49 & 70.000 & $5,321.3$ & 76,0 \\
1993 & 49 & 70.000 & $3,727.6$ & 53,2 \\
1994 & 49 & 70.000 & $2,564.0$ & 36,6 \\
1995 & 45 & 68.000 & $1,374.8$ & 20,2 \\
1996 & 49 & 70.000 & $1,332.0$ & 19,0 \\
1997 & 50 & 78.000 & $2,716.2$ & 34,8 \\
1998 & 52 & 83.000 & $3,149.8$ & 37,9 \\
1999 & 55 & 86.000 & $3,618.6$ & 42,0 \\
\hline Mean & 49 & 73.000 & $3,995.5$ & 54,7 \\
\hline
\end{tabular}

These observations indicate that in the north-eastern region of Brazil, the reservoirs can play an important socio-economic role in a short-term rural development programme by effective utilization of local resources thus opening new economic niches and promoting opportunities for fishing and aquaculture with significant earnings for the regional economy. 
M.A. Iragashiet al.

\section{Production perspectives}

\section{Fingerling production}

It is envisaged to increase the fresh water fish production in the reservoirs in the north-eastern region of Brazil to 176,000 tons/yr of which 170,000 tons are expected from net-cage culture and 6.000 tons from organized capture fisheries in public reservoirs (DNOCS 2000). For this, 630 million fingerlings will be required annually. The autarchy had committed to increase its present annual production of 25 to 75 million fingerlings, and the rest has to come from private enterprises (Silva 2001).

\section{Availability of land and water}

Due to the inconsistency of rains, the best way to guarantee a continuous supply of water for agriculture and aquaculture is by constructing reservoirs that retain rain water for later distribution during drought periods as done in many Asian countries including Sri Lanka, India and Thailand (De Silva and Amarasinghe 1996). Nevertheless, studies done in the early 1980 s showed the feasibility of carrying out irrigation projects in a 454,687 ha area in the drought stricken north-eastern region of Brazil (Silva 2001). It has also been shown that around 9100 ha, which is not arable due to salinization, could be used for aquaculture to produce around 636000 tons of fish per annum (Silva 2001). The agriculture and aquaculture can bring about significant socio-economic changes in this area.

\section{Environmental protection}

Emphasis should also be given to carrying out aquaculture activities without significant adverse environmental impacts. The current environmental legislation should also be thoroughly studied and adhered to.

The government and the community have a fundamental role of protecting the environment of reservoirs, rivers and lakes as they are common pool resources. In tilapia culture, it is necessary to consider the legislation on water management, coastal management and environmental protection in order to achieve a sustainable socio-economic development.

\section{Net cage culture}

The north-eastern region of Brazil is blessed with environmental conditions suitable for net cage culture in reservoirs. Further, researches have shown that there is a high potential for intensive pisciculture in presently unexploited water bodies in the north-eastern region. Within this context, tilapia production in nets cages may become an excellent option to make good use of reservoirs and estuarine areas in this region. However, the production cost of net-cages is higher than that of earthen ponds. On the 
Tilapia in Brazil

other hand, fish cultivated in net-cages grow faster and it is believed that their flesh is more tender and tastier than those of captured fish.

\section{Quality of life of the rural poor}

It is worth emphasizing that tilapias culture in reservoirs is of great importance as those who consume these fish have a very low income and a low quality of life. Due to the existence of capture fisheries in public and private reservoirs and the low price of tilapias, a large segment of the northeastern population where around 51.000 pcople depend directly on fishing has access to animal protein (Gurgel 1998).

\section{Strategies for management}

In the reservoir fisheries of the north-eastern region, wives and children of the fishermen are also engaged in fishing activities such as catching of fish, fish processing and repairing fishing gear. Since there are nearly 5500 fishermen involved in fishing activities in the 94 public reservoirs in the north-eastern rcgion of Brazil, assuming that there are 5 members in a fishing family in average, nearly 27500 people in this region are directly benefited by fishing in these rescrvoirs (Silva 2001).

Value addition through processing techniques is also necessary. This will further enhance the employment generation and income to the local community.

Hence, by incorporating tilapia aquaculture in rural development programmes, income of the rural communities could be increased. This will contribute to enhance their quality of life in addition to providing animal protein to combat malnutrition. As such, the exodus of people from rural areas may also be minimized.

The number of professional fishermen in the public reservoirs in the north-eastern region of Brazil is observed to be decreasing in the recent past probably due to the shrinking of reservoir area caused due to the irregularity of the rainy season, low fish production caused due to over-fishing and bashful stocking programmes (Silva 2001).

The problem of declining water level in the reservoirs may be partially overcome by the transposition of hydrographic reservoirs as done by the Valley of Sao Francisco Developing Company to rivers of the semiarid region.

In order to meet the demands of the people, the Valley of Sao Francisco Developing Company developed the Semi-arid Project, with an idca of fetching water to the reservoirs of the River Parana basin and Furnas reservoir in Minas Gcrais. 
Further, there are several other projects, which show the possibility of generating wealth and getting rid of poverty in rural areas. Nevertheless, the colonies and fishermen's associations of the reservoirs must be strengthened to meet the social requirements such as medical assistance, elementary education, etc. and to encourage the flow of credit and technical assistance into the fishing community (Silva 2001). Despite all the advantages in fishing and aquaculture of tilapia, recent economic development in the State of Ceara is based on generating revenue for the large enterprises and companies located in other areas of Brazil. On the other hand, if an organized and planned development policy is implemented for tilapia production, the semi-arid north-eastern region would not depend on government aid. Thus, the government should provide greater incentives to the families of this semi-arid region through tilapia cultivation projects, which will also help to prevent rural exodus. It is true that some of these programs have not shown satisfactory results due to lack of resources. Nevertheless, tilapia contributes towards the reduction of malnourishment of the rural communities. There is a need to apply technology generated through research, improve government offices and provide more investment by employing qualified personnel. Furthermore, fiscal control and administration of reservoir fishing carried out in the past must be reactivated.

\section{Investments for tilapia culture}

Production cost of a cultured species may vary from region to region due to differences in climatic and topographical conditions, technology applied, and the distance from culture areas to the site of seed production and to the market. It can also vary from farm to farm within the same region due to differences such as farm size and the technology applied. The major costs involved in the aquaculture of tilapia include the costs of construction of ponds, food, fertilizer, aquaculture equipment, labour, property leasing, packing, processing and distribution.

Fish cultivation in cages originated at the Delta of the River Yangtze in China over 700 years ago. However, tilapia cultivation in cages began in the USA and the Ivory Coast in the 1970s. This technique has spread throughout the world now.

The decree that regulates the use of federal public waters for aquaculture in Brazil was signed in April 2001. According to this decree, action has to be taken to popularize tilapia cultivation in net cages (Ostrenskey and Borghetti 2001).

A system consisting of 32 individual net cages is considered as the minimum technically feasible size. The size of a net cage is around $2 \mathrm{mx}$ $2 \mathrm{~m} \times 1 \mathrm{~m}$. The economic cost benefit analysis involving internal return rate, levelling point, capital return rate, profit and invested capital return 
time indicates that aquaculture in net cages is feasible and profitable (Silva 2001).

The tilapia fingerlings of $20-100 \mathrm{~g}$ in weight take $3-6$ months in net cages to reach the marketable size of $400 \mathrm{~g}$. In pond culture, such fingerlings take a longer time to reach that size. In order to get high quality individuals, fingerlings should be purchased from companies that warrant their good lineage.

Administration of cultivation in net cages is also is simple. The animals may be fed three times a day with floating formulated feed. During harvesting all the tilapias could be caught easily from the net cages.

The production cost of tilapia in net cages is approximately $R S$ $1.37 / \mathrm{kg}$. This amount is $20-30 \%$ higher than the production cost in pond culture because in net cages tilapias are exclusively fed on formulated feed while in pond culture fertilization may also be carried out to generate natural food. One $\mathrm{kg}$ of cultured tilapia could be marketed at a price ranging from RS 1.80 to 2.50 .

Net-cages should be installed in places where there are no strong currents and minimum depth is $2.5 \mathrm{~m}$. Further, they should be installed away from the routes of boats and jet-skis as such activities may cause stress to the fish retarding their growth. A legal authorization is also necessary to install net-cages.

Ono \& Kubitza (1999) analyzed some economic parameters for aquaculture of Nile tilapia in net cages as follows.

$\begin{array}{lrr}\text { Cost of preparation of a net cage measuring } 2 \mathrm{~m} \times 2 \mathrm{~m} \times 1 \mathrm{~m} & -\mathrm{R} \$ 23.50 \\ \text { Cost of } 400 \text { fingerlings (at a rate of } \mathrm{R} \$ 0.10 / \text { fingerling) } & -\mathrm{R} \$ 40.00 \\ \text { Cost of ration (R\$ } 0.47 / \mathrm{kg} \text { ) } & -\mathrm{R} \$ 160.74 \\ \text { Manual labour } & -\mathrm{R} \$ 60.00 \\ \text { Total operational cost } & -\mathrm{R} \$ 260.74 \\ \text { Paying off debts and harvest interest (4 month) } & \\ \quad \text { Net cage + } 1.5 \% \text { monthly } & -\mathrm{R} \$ 4.99 \\ \quad \text { Operational interest } & -\mathrm{R} \$ 7.96 \\ \quad \text { Total cost } & -\mathrm{R} \$ 273.69\end{array}$

(Operational cost + Paying off debts and harvest interest)

Maximum total production within 4 -month culture cycle- $200 \mathrm{~kg} / \mathrm{m}^{3}$

$\begin{array}{lll}\text { Cost of production of } 1 \mathrm{~kg} \text { of fish } & -\mathrm{R} \$ & 1.37\end{array}$

Minimum total revenue

- R\$360.00

(at a minimum sale price of $\mathrm{R} \$ 1.80 / \mathrm{kg}$ )

Minimum profit/net cage for 4 months

- RS 86.31.

Some producers may obtain $400 \mathrm{~kg}$ of fish from a net cage of $2 \mathrm{~m} \mathrm{x}$ $2 \mathrm{~m} \times 1 \mathrm{~m}$ in every 4 months. Thus the annual production from 100 net cages of that size would be 120 tons. According to Silva (2001) more than 150,000 tons of tilapia could be produced annually in net cages using only 


\section{M.A. Iragashi et al.}

$0.5 \%$ of the water area of the public reservoirs in the northeastern region of Brazil. If these are sold at a price of $\mathrm{R} \$ 1.80 \mathrm{per} \mathrm{kg}$, the annual income from net cages could be around RS 270 million.

According to Silva (2001), the capital invesiment required for the construction of a 1 ha pond and to purchase equipment required for the aquaculture of fish in that pond is around RS 34,200.20 (Table 15). The annual production from this 1 ha pond is estimated to be 27 tons. As such the annual income is estimated to be $R \$ 48,600.00$ from a 1 ha pond if fish are sold at RS 1.80 per $\mathrm{kg}$.

Table 15: The capital investment required for the construction of a 1 ha pond and to purchase equipment required for aquaculture of fish in that pond in the state of Ceará (Source: Silva 2001).

\begin{tabular}{lr}
\hline Item & RS \\
\hline Preparation of technical proposal & $1,966.56$ \\
Pond construction & $24,747.87$ \\
Supplying and draining of water & $2,542,15$ \\
Initial preparation & 186.19 \\
Aerators (5) & 2.567 .95 \\
Fishing nets & 682.51 \\
Other equipment & $1,497.97$ \\
\hline Total & $34,191.20$ \\
\hline
\end{tabular}

The annual operational cost of aquaculture pond of 1 ha stocked with male Nile tilapia in the State of Ceará is around $R \$ 44,000.00$ (Table 16). Thus the annual profit from 1 ha pond is around $R \$ 4600.00$ while the minimum profit from 100 net cages with a total area of $400 \mathrm{~m}^{2}$ is around RS $25,900.00$.

In the recent past, the North-east Constitutional Fund has been the main source of financial assistance for the capture and culture fisheries in the northeastern region of Brazil. Some funds were made available by Banks such as Bancos do Nordeste (BN) and Estaduais. Credit lines are also available for the aquaculture of tilapia in the North-eastern region with payment offers of up to 12 years, 4 year debt delay and interest rates of $5 \%$ per annum (Silva 2001).

However, for more effective aquaculture production, more credit facilities to the producers, more unity among institutions, better incentives for research and aquaculture extension and better training for aquaculturists are required. It is also necessary to improve the nutritional quality of the diet given to cultured tilapia. The formulated feed should be prepared using low-cost ingredients. The formatted feed should be incorporated with 


\section{Tilapia in Brazil}

Table 16: Annual operational cost of 1 ha pond stocked with male Nile tilapia with emergency aerators and without renewal of water (Source: Silva 2001).

\begin{tabular}{lr}
\hline ITEM & R\$ \\
\hline Permanent labourers $(2)^{1}$ & 7.507 .20 \\
${\text { Temporary labourers }(1)^{2}}^{\text {Fingerlings }^{3}}$ & 180.00 \\
Ration $^{4}$ & $3,360.00$ \\
Lime $^{5}$ & $23,760.00$ \\
Organic manure $^{6}$ & 240.00 \\
Medicaments etc. & 225.00 \\
Technical assistance & 300.00 \\
Electrical power & 480.00 \\
General maintenance $^{7}$ & $2,520.00$ \\
Marketing expenses & $1,709.56$ \\
Other expenses $^{9}$ & $2,376.00$ \\
\hline Total & $1,279.49$ \\
\hline
\end{tabular}

${ }^{1}$ Wages $+36 \%$ social incumbencies; ${ }^{2}$ Casual labour for maintenance total of 36 days/year, at a rate of $\mathrm{R} \$ 5.00$ per day; ${ }^{3} 80,000\left(4 \mathrm{fish} / \mathrm{m}^{2}\right) ; 43,200 \mathrm{~kg}$, at a rate of $\mathrm{R} \$ 0.55$ per kg; ${ }^{5} 2000$ at a rate of $R \$ 0.12 / \mathrm{kg} ;{ }^{6} 5,000 \mathrm{~kg}$ for Nile tilapia, at a rate of $\mathrm{R} \$ 45.00$ per ton.; ${ }^{7} 5 \%$ of investments; ${ }^{8} 3 \%$ income; ${ }^{9} 5$ \% production costs.

additives to reduce disease risks and growth promoters to enhance growth and survival. Further, aquaculture should be carried out in an environmentally friendly manner. It is also necessary to develop suitable fishing technologies in reservoirs and rivers based on scientific research that warrant equilibrium between conservation and harvesting of aquatic organisms.

\section{Conclusions}

According to the information already available, it appears that with the development of aquaculture of Nile tilapia and capture fisheries in the reservoirs, it will be possible to alleviate poverty and overcome the uncqual distribution of income among the rural communities in the north-eastern region of Brazil.

Thus, with the implementation of new appropriate aquaculture programmes, the living conditions of the rural communities in the interior of the north-eastern region of Brazil could be improved by creating employment opportunities. The tilapia produced by aquaculture can be exported, thus conciliating a more favourable balance in the economy and distribution of benefits within the region. 
M.A. Iragashiet al.

One of the basic objectives would also be the integration of intra and inter-regional markets, which would subsequently lead to a reduction in the prices of cultured fish to a level that could be afforded by the rural population. By intensifying production in reservoirs, the rural villagers could become the supply centres of fish for local and international markets.

Harvesting tilapia from reservoirs is finite due to natural bioecological limitations. Due to this inevitable situation, hopes are placed in stocking reservoirs and carrying out aquaculture in ponds and net cages. Therefore, another important objective is to increase the production of tilapia fingerlings in the research stations in order to provide the sufficient number of fingerlings required for stocking in reservoirs, ponds and net cages.

Based on the present studies, it can be concluded that there is a great potential in the north-eastern region of Brazil to increase aquaculture production of tilapia, which would help to enhance the living conditions of the rural people.

\section{Acknowledgement}

The authors are grateful to Professor C.H. Fernando, University of Waterloo, Canada for suggesting to publish this paper in Sri Lanka. Thanks are also due to Professor Jose Tundisi International Centre for Ecology, Sao Carlos, Brazil, who translated the paper from Portuguese to English.

\section{References}

Alves, A. 2001.

Piscicultura:primeiros passos. Revista Brasileira Agropecuária, 1 (12): $13-17$.

Carvalho, I. 2001.

Nao existem políticas de desenvolvimento regional. In Conhecendo o Semi- árido. Universidade Pública. Ediçōes UFC. 2 (8): 29.

Dc Silva S.S. \& U.S. Amarasinghe 1996.

Reservoir fisheries in Asia. In: Perspectives in Asian Fisheries (S.S. De Silva ed.) pp. 189-216, Asian Fisheries Society. Manila, Phillippines.

DNOCS, 2000.

Quadros Informativos sobre a Produção do Pescado em Açudcs com Administração de Pesca nos Anos de 1948-1999, Fortaleza:

Diretoria de Pesca e Piscicultura, 180 p.

FAO 1999.

Aquaculture Production Statistics.1988-1997. FAO Fisheries Circular. No. 815, FAO, Rome, 203. 
Tilapia in Brazil

Gurgel, J.J.S. 1998.

Potencialidade do cultivo de tilápia no Brasil. Anais Do Primeiro Congresso Nordestino de Produção Animal. 345-352.

Gurgel, J.J.S. 2001.

Pesca nos açudes no Estado do Ceará relacionada com alguns fatores limnológicos. Dissertação submetida à coordenação de pósgraduação em Engenharia de Pesca, como requisito parcial para a obtenção dograu de mestre em Engenharia de Pesca, Area de concentração aqüicultura. $133 \mathrm{p}$.

Lima, A.O. 2001a.

Promessa de lucro que virou realidade. Revista Brasileira Agropecuária 1(12): 30-33.

Lima, A.O. 2001b.

Cadeia produtiva: elos ainda fracos. Revista Brasileira Agropecuária 1(12): 34-39.

Lovshin, L.L. 2000.

Tilápia culture in Brazil. In: Tilapia Aquaculture in the Americas,

Vol 2: (B.A. Costa Pierce \& J. E. Rakocy eds.), pp. 133-140, The

Worid Aquaculture Society, Baton Rouge, Lousiana, United States.

MAA 2000.

(Ministério da Agricultura e do Abastecimento) Programa Nacional de Apoio à Competitividade e à Sustentabilidade da Cadeia da Tilúpia. Brasilia, 5p.

Ono, E.A. \& F. Kubitza, 1999.

Cultivo de peixes em tanques-rede. 2 ed. Rev . e Ampl. - Jundiai.

$68 \mathrm{p}$.

Ostrensky, A. \& J.R. Borghetti 2001.

Espécies cultivadas na aqüicultura brasileira. Revista Brasileira Agropecuária 1(12): 18-27.

Ribeiro, L.P., M.O.T. Miranda, L.C. Lima \& E.D. Holanda 2000.

Aquacultura empresarial. Informe Agropecuário, Belo Horizonte 21: 5-9.

Silva, J.W.B. 2001.

Contribuição das tilápias (pisces: cichlidae) para o desenvolvimento da piscicultura no Nordeste brasileiro, especialmente no estado do Ceara. Dissertação submetida à coordenação de pósgraduação $\mathrm{em}$ Engenharia de Pesca, como requisito parcial para a obtenção dograt de mestre em Engenharia de Pesca, Área de concentração aqüicultura $193 \mathrm{p}$. 